


\section{STANDARD REFERENCE MATERIALS FOR COMBUSTION CALORIMETRY}

George T. Armstrong and Walter H. Johnson

Thermochemistry Section

Physical Chemistry Division

Institute for Materials Research

National Bureau of Standards

Washington, D. C. 20234

This report is prepared as a presentation for the Fourth International Conference on Chemical Thermodynamics, Baden, Austria, 3-7 September 1973. The complete description of the experiments will be presented in future publications which will receive general distribution.

Please consult the NBS Office of Technical Information and Publications to obtain the proper citations.

July 1973

Interim Report

\section{Prepared for}

Office of Standard Reference Materials

National Bureau of Standards

Washington, D. C. 20234

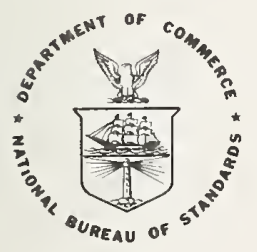

U. S. DEPARTMENT OF COMMERCE, Frederick B. Dent, Secretary NATIONAL BUREAU OF STANDARDS, Richard W. Roberts, Director 

, 


\section{Standard Reference Materials for Combustion Calorimetry}

George T. Armstrong and Walter H. Johnson

\section{Abstract}

Combustion measurements using a rotating bomb adiabatic aneroid calorimeter have been used to make a preliminary evaluation of ten substances as potential thermochemical reference materials for combustion of organic compounds containing N, S, Cl and F. p-chlorobenzoic acid, p-fluorobenzoic acid, and urea are recommended for acquisition, certification, and distribution. Thianthrene may also be suitable. For the ten substances including in addition to the above: $0-$ and m-chlorobenzoic acids, o-fluorobenzoic acid, nicotinic acid, acettanilide, and creatinine, typical combustion data are given, showing corrections applied; and mean thermodynamic functions at $25^{\circ} \mathrm{C}$ are given together with error estimates. The results are compared with other work. Recommendations and a discussion of the role of standard reference materials for thermochemistry are given. 


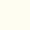


Table of Contents

Page

Abstract ..................... . . . . . i

1.0 Introduction . . . . . . . . . . . . . . 1

2.0 Calorimeter . . . . . . . . . . . . 5

3.0 Experimental Studies . . . . . . . . . . . 7

4.0 Substances Studied .................. 13

4.1 F1uorobenzoic acids . . . . . . . . . . . . 13

4.2 Chlorobenzoic acids . . . . . . . . . . . . 13

4.3 Acetanilide . . . . . . . . . . . . 14

4.4 Urea (carbamide); $\left(\left(\mathrm{NH}_{2}\right)_{2} \mathrm{CO}\right)$........... 14

4.5 Nicotinic acid (pyridine-3-carboxylic acid;

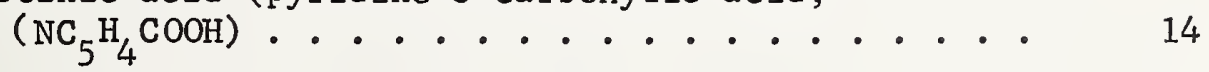

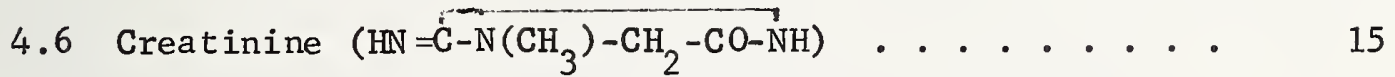

4.7 Thianthrene $\left(\left(\mathrm{C}_{6} \mathrm{H}_{4}\right)_{2} \mathrm{~S}_{2}\right)$................ 15

5.0 Recommendations .................. 15 
STANDARD REFERENCE MATERIALS FOR COMBUSTION CALORIMETRY ${ }^{1}$

GEORGE T. ARMSTRONG AND WALTER H. JOHNSON

T'hermochemistry Section

Physical Chemistry Division, Institute for Materials Research National Bureau of Standards, Washington, D.C. 20234 U.S.A.

\subsection{Introciuction}

Standard reference materials (SRM's) for combustion calorimetry serve two principal purposes. (1) A primary standard reference material provides a means of calibrating a calorimeter using a process similar to those which are to be studied with the calorimeter. The value for the energy of combustion determined in a national standardizing laboratory provides the experimentalist with a scale of measurement consistent with the energy scale of the measurement system. In the case of energy measurements this is the joule as established in the International System of Units. (2) A secondary standard reference material provides a well characterized material of a particular class of substances, which can be studied in many different laboratories. As the material is the same in all measurements, observed differences are cue either to differences in technique or to differences in the calorimeters. If the experimental problems of measurement have been worked out by competent research workers in the field recommended procedures for use of the naterial may also be available. Such a material can be used by the experimentalist with some degree of confidence to establish his capability of naking accurate measurements on substances of this class. The possibility of differences in performances of calorimeters may not be neglected. This is a less pronounced problem in bomb calorimetry than in same other calorimetric processes.

For many years benzoic acid has been available as a primary SRM. It was available for this purpose as early as 1911 from the U.S. National Bureau of Standards, Stratton (1911), and it, as well as other substances, had been used by Stohman, Kleber, Langbein, and Offenhaver (1893). Technologically the principal use of this standard has been for caliurating bomb calorimeters to be used in laboratories testing foods and other agricultural products, fuels, as well as other combustible materials and energy sources. The standard has permitted rapid, inexpensive determinations of heating values of moderate accuracy.l However this particular SRM was found to be of good enough quality even for the most precise scientific studies of combustion energies, and its use throughout the

\footnotetext{
This paper is available as NBS Internal Report 73-158.
} 
worli in determining energies of combustion of pure substances has cause a large friction of the total thermochemical data base to be derived from the certified energy of combustion.

Almost from the beginning, the desirability of secondary SRM's was recognized, but these materials have never been provided by a national standardizing laboratory to the extent requested. The subject was reviewed by Wadiington (1956).

The reason secondary standard reference materials have not previously been provided is probably in large part an economic matter. NBS standard reference materials are sold at a price to compensate for their production, certification, and sale. An SRM of a general character, such as benzoic acid has a large enough market to permit sale at a very moderate price. However, despite the fact that a number of laboratories have a very urgent need for secondary SRM's, the actual number of potential users is quite sma11. The estimated number of users in any year may be of the order of ten for a particular standard reference material as specialized as a thermochemical standard. The great benefit to the thermochemical community and the improvement of the validity of thermochemical data are therefore important factors in justifying a series of materials.

Materials already in use for combustion calorimetry standards, and materials previously proposed for combustion standards are listed in Table 1, including both primary and secondary standards.

One purpose of a secondary SRM in thermochemistry is to give the user confidence in his ability to make accurate measurements after having calibrated his apparatus. This seems to be primarily a didactic use or a reassurance. The novice training to do bomb calorimetry would be reassured if, after calibrating his apparatus, he could then make measurements on a simple, straightforward process and obtain results that he could compare with known correct values. This is the primary argument used for another C, $\mathrm{H}, \mathrm{O}$ compound such as succinic acid. A possible variation of such a material from benzoic acid is a significantly different specific enthalpy of combustion. The hydrocarbon, 2,2,4-trimethylpentane, gives the user an opportunity to test his skill at handling a volatile hydrocarbon. In this respect it is partially satisfactory, but still fails to cope with an important problem in petroleum test laboratories: the changing heat value of a volatile fuel mixture on standing, due to fractional vaporization of the more volatile components. 
Substance

\begin{tabular}{|c|c|c|}
\hline hydrogen & $\mathrm{H}_{2}(\mathrm{~g})$ & flow calorimetry \\
\hline me thane & $\mathrm{CH}_{4}(\mathrm{~g})$ & flow calorimetry \\
\hline $2,2,4-$ trime thyl pentane & $\mathrm{C}_{8} \mathrm{H}_{18}(\&)$ & volatile hydrocarbon \\
\hline naphthalene & $\mathrm{C}_{10} \mathrm{H}_{8}(\mathrm{c})$ & formerly available \\
\hline benzoic acid & $\mathrm{C}_{7} \mathrm{H}_{6} \mathrm{O}_{2}(\mathrm{c})$ & transfer standard \\
\hline sucrose & $\mathrm{C}_{12} \mathrm{H}_{22} \mathrm{O}_{11}(\mathrm{c})$ & formerly available \\
\hline salicylic acid & $\mathrm{C}_{7} \mathrm{H}_{6} \mathrm{O}_{3}(\mathrm{c})$ & C. $\mathrm{H}, \mathrm{O}$-compound \\
\hline succinic acid & $\mathrm{O}_{4}(\mathrm{c})$ & $\mathrm{C}, \mathrm{H}, \mathrm{U}$-compound \\
\hline acetanilide & $\mathrm{C}_{8} \mathrm{H}_{9} \mathrm{NO}(\mathrm{c})$ & \\
\hline hippuric acid & $\mathrm{C}_{9} \mathrm{H}_{9} \mathrm{NO}_{3}(\mathrm{c})$ & \\
\hline urea & $\mathrm{CH}_{4} \mathrm{~N}_{2} \mathrm{O}(\mathrm{c})$ & $\mathrm{N}$-compound \\
\hline nicotinic acid & $\mathrm{C}_{6} \mathrm{H}_{5} \mathrm{NO}_{2}(\mathrm{c})$ & \\
\hline THMAM* & $\mathrm{C}_{4} \mathrm{H}_{11} \mathrm{NO}_{3}(\mathrm{c})$ & \\
\hline thianthrene & $\mathrm{H}_{8} \mathrm{~S}_{2}(\mathrm{c})$ & \\
\hline thioglycolic acid & $\mathrm{C}_{2} \mathrm{H}_{4} \mathrm{O}_{2} \mathrm{~S}(l)$ & \\
\hline sym-diphenylthiourea & $\mathrm{C}_{13} \mathrm{H}_{12} \mathrm{~N}_{2} \mathrm{~S}(\mathrm{c})$ & S-compound \\
\hline sulfanilamide & $\mathrm{C}_{6} \mathrm{H}_{8} \mathrm{~N}_{2} \mathrm{O}_{2} \mathrm{~S}(\mathrm{c})$ & \\
\hline benzotrifluoride & $5{ }_{3}(l)$ & \\
\hline $\begin{array}{l}\text { p-fluorobenzoic acid } \\
\text { pentafluorobenzoic acid }\end{array}$ & $\begin{array}{l}\mathrm{O}_{2} \mathrm{~F}(\mathrm{c}) \\
\mathrm{O}_{2} \mathrm{~F}_{5}(\mathrm{c})\end{array}$ & F-compound \\
\hline $\begin{array}{r}\text { m-trifluor ome thylbenzoic } \\
\text { acid }\end{array}$ & $\mathrm{C}_{8} \mathrm{H}_{5} \mathrm{O}_{2} \mathrm{~F}_{3}(\mathrm{c})$ & \\
\hline trichlorophenol & $\mathrm{C}_{6} \mathrm{H}_{3} \propto \mathrm{C}_{3}$ (c) & \\
\hline m-chlorobenzoic acid & $\mathrm{C}_{7} \mathrm{H}_{5} \mathrm{O}_{2} \mathrm{Cl}(\mathrm{c})$ & Cl-compound \\
\hline p-chlorobenzoic acid & $\mathrm{C}_{7} \mathrm{H}_{5} \mathrm{O}_{2} \mathrm{Cl}(\mathrm{c})$ & \\
\hline o bromobenzoic acid & $\mathrm{C}_{7} \mathrm{H}_{5} \mathrm{O}_{2} \mathrm{Br}(\mathrm{c})$ & Br-compound \\
\hline m-iodobenzoic acid & $\mathrm{C}_{7} \mathrm{H}_{5} \mathrm{O}_{2} \mathrm{I}(\mathrm{c})$ & I-compound \\
\hline triphenyl phosphine oxide & $\mathrm{C}_{18} \mathrm{H}_{150 \mathrm{P}}(\mathrm{c})$ & P-comp ound \\
\hline
\end{tabular}

*tris (hydroxyme thyl) aminome thane 
Each additional element introduced into a compound also introduces new problems. These problems include (a) obtaining completeness of combustion; and (b) obtaining a definite set of products. Thus, for instánce a compound containing little hydrogen may smoke or char because the flame is not hot enough to obtain complete combustion. This is a relatively simple problem in many cases, though troublesome. The techniques for obtaining more nearly complete combustion are well known (higher oxygen pressure, promoters, lighter weight crucible and other supports); also the techniques for determining that combustion is complete are known $\left(\mathrm{CO}_{2}\right.$ determination, $\mathrm{CO}$ determination, odor of products, absence of soot). Much more subtle problems are to establish the nature of the products and to devise experimental conditions such that a consistent and analyzable set of products is obtained, when other elements than $\mathrm{C}, \mathrm{H}, \mathrm{O}$ are present.

Typical problems are: (a) the formation of acid products when group V, VI, and VII elements are present, (b) the formation of elements in various oxidation states when multiple valency can occur. Acid products can be determined by titration, but if more than one acid is present the separate identification may be more difficult. Acid products may be corrosive to the calorimeter parts and side reactions may therefore occur. Various oxidation states lead to other analytical problems, as when $\mathrm{Cl}_{2}$ may be formed along with $\mathrm{HCl}$ from organic chlorine compounds. The establishment of combustion conditions in which the complexity of the products is minimized is a reasonable goal because it simplifies the product analysis.

The problem of criteria for selection of suitable secondary reference materials does not have a simple answer. This becomes evident as soon as one tries to choose a substance for a particular class--fluorine compound--for example. Should the compound have a high proportion or a low proportion of fluorine? It turns out that if $\mathrm{F}$ is bound to $\mathrm{C}$ in the compound, the probability of finding $\mathrm{CF}_{4}$ or other $\mathrm{CF}$ compounds in the products is increased. As found by Good, Scott, Waddington (1956) the amount of $\mathrm{CF}_{4}$ is determined by the ratio of $\mathrm{H}$ to $\mathrm{F}$ in the combustion mixture--low $\mathrm{H} / \mathrm{F}$ leading to high $\mathrm{CE}_{4}{ }^{\circ} \mathrm{As}_{4}$ is difficult to determine if $\mathrm{CO}_{2}$ is also to be determined this presents a problem. One solution is tc select a high-as well as a low-fluorine sample. This approach leads to conceptual difficulties because it increases the number of required samples and there is no discernable limit to such an increase. Any new set of conditions could require a different reference material.

A possible solution to this dilemma is to set a criterion of difficulty for problems to be solved by the use of a standard reference 
material. Thus an SRM for a given set of elements should exemplify a characteristic problem which must be solved in order to obtain satisfactory measurements.

An important function of reference materials is to help locate errors in measurements by different individuals, different procedures and different kinds of instruments. Thus too close adherence to a ritual procedure and common design of calorimeter is shortsighted and likely to obscure errors rather than reveal them.

Recognizing the importance of tracing errors in thermochemistry and of the important part reference materials may play in obtaining an internally self consistent set of thermochemical values inter-relating the chemical substances, the National Bureau of Standards undertook the preparation of a series of thermochemicalstandard reference materials containing the elements $\mathrm{N}, \mathrm{F}, \mathrm{Cl}, \mathrm{Br}, \mathrm{I}, \mathrm{S}$, and $\mathrm{P}$, individually in organic compounds This is a preliminary report of the investigations that have been carried out in the study. The work involved collaboration between the Thermoshemistry Section and the Office of Standard Reference Materials, which provided samples for study and some financial support for the work. The work that has been done is primarily a calorimetric study of the combustion energy of selected compounds which offer potentiality as standard reference materials.

\subsection{Calorimeter}

The calorimeter used in the experiments was designed, constructed and tested by Prosen and Johnson. It is an aneroid, vacuumjacketed calorimeter with adiabatic shield, and rotating bomb. The calorimeter assembly is illustrated in figure 1. The bomb is shown in figure 2. A principal problem in an aneroid calorimeter is to obtain temperature distributions known well enough that heat transfer to the surroundings does not create a large error. The laminated construction is the design feature which solves this problem, when combined with the vacuum jacket and polished gold surfaces on bomb exterior and shield interior.

The calorimeter is a comparison device, comparing the energy of combustion of the substance under study with the energy of combustion of the reference substance, benzoic acid (NBS SRM 39i). The certificate value, $26.434 \pm 0.003 \mathrm{~kJ} \cdot \mathrm{g}^{-1}$, was used for the energy of reaction of benzoic acid. On the basis of calibration measurements the energy equivalent of the calorimeter is about $2519 \mathrm{~J} \cdot \mathrm{K}^{-1}$, the value being determined accurately with an uncertainty $(2 \mathrm{sdm})$ of about 0.005 percent for each series of experiments.

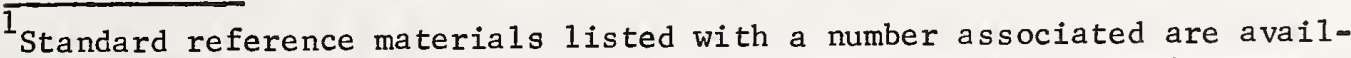
able from the Office of Standard Reference Materials, National Bureau of Standards, Washington, D.C. 20234.
} 


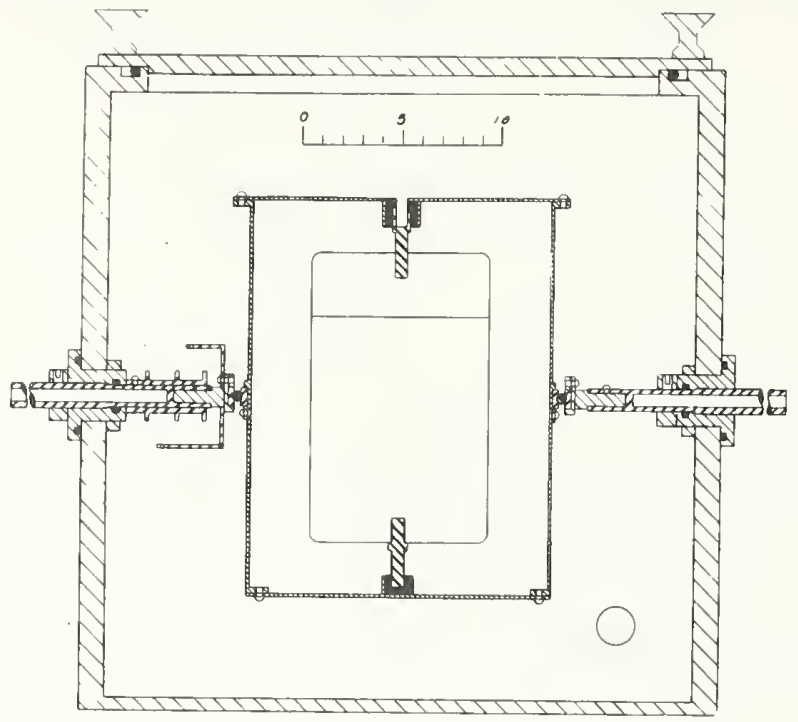

Figure 1. Scheratic view of calorimeter assembly. (An early diagram) The outer, room-temperature, evacuated box is shown, with the rotating adiabatic shield. The shield rotates on two axes following a pre-programmed routine. The bomb, (see fig. 2 for detail), is contained within the adiabatic shield.

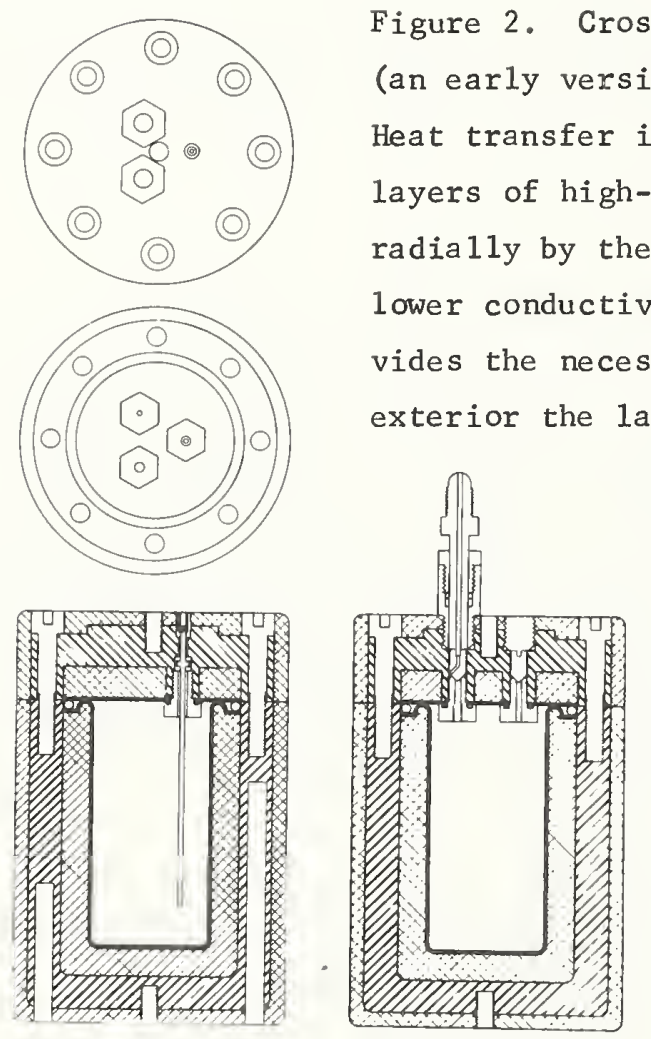

igure 2. Cross section of aneroid calorimeter bomb early version) showing laminated construction. is aided laterally by inner and outer layers of high-conductivity metals, and hindered radially by the laminated construction and by the ower conductivity of the steel layer, which processary strength. From interior to inations consist of platinum liner (about $1 \mathrm{~mm}$ ), silver (about $12 \mathrm{~mm}$ ), stee1 (about $12 \mathrm{~mm}$ ), 'silver (about $7 \mathrm{~mm}$ ), gold plate. The bomb is suspended within the adiabatic shield by two axial pins inserted in holes shown in top and bottom.

Temperatures are measured by a ca'librated capsule-type platinumresistance thermometer inserted in the bomb wal1. Temperature differences between calorimeter bomb and adiabatic shield are measured by copper-constantan thermocouples. The output voltage is used to regulate the adiabatic shield temperature in such a way as to minimize the tem- 
perature difference. Smal1 temperature drifts (due

to thermometer heat) are observed in the bomb temperature during the rating periods, and these drifts are taken into account in calculating the temperature rise. Temperature rise values ranged from about one kelvin to about three kelvins and were reported to $10^{-6} \mathrm{~K}$.

The energy equivalent of the standard calorimeter system was adjusted for variations in the average temperature of the experiments, for heat capacities of minor components added to the calorimeter, and for the heat capacities of the initial contents of the bomb. The first two adjustments amounted to less than one $\mathrm{J} \cdot \mathrm{K}^{-1}$. The heat capacities of the bomb contents, accurately calculated in each experiment, contributed 15 to $20 \mathrm{~J} \cdot \mathrm{K}^{-1}$, mostly due to the water added for dissolving acids formed. The small energy equivalent of the calorimeter makes possible the use of comparatively small samples. Depending on the chemical constitution of the substance, samples of 0.1 to $0.7 \mathrm{~g}$, releasing 2 to $8 \mathrm{~kJ}$, are used to obtain the desired temperature increments of one to $3 \mathrm{k}$.

\subsection{Experimenta1 Studies}

Typically a series of six experiments, with occasional variations of one or two in number, was made with each potential reference material. The experiments are discussed briefly below for each substance. A typical experiment is summarized for each substances in table 2. Data listed for each substance are experiment number; observed total heat, $\mathrm{Q}_{\text {obs }}$; correction for ignition energy, $\mathrm{q}_{\text {ign }}$; correction for decomposition of $\mathrm{HNO}_{3}, \mathrm{q}_{\mathrm{N}}$; Washburn correction, $\mathrm{q}_{\mathrm{W}}$; correction for adjustment to standard final temperature, $\mathrm{q}_{\mathrm{Tf}}$; energy of standard reaction, $\mathrm{U}_{\mathrm{F}}-\mathrm{U}_{i}$; mass of sample, $\mathrm{m}_{\mathrm{S}}$; specific standard internal energy of reaction at selected final temperature, $\|_{c}^{\circ}$ (at Tf). Special entries for some substances when listed are mentioned in the paragraph relating to the substance.

The reaction's carried out approximated the stoichiometric equations listed in Table 3. The observed energy measurements were adjusted to correspond to these reactions. In Table 4 are given average thermodynamic quantities and uncertainties of these quantities corresponding to the equations in Table 3. The final temperature, Tf, to which the experi. mental reaction was referred, and the mean specific standard internal energy of combustion, $-{\Delta J_{c}^{\circ}}_{c}^{\text {at at }}$ Tf are given together with the number of experiments and the standard deviation of the mean. Also given are the molar standard internal energy of combustion, $\Delta_{c}^{\circ}$, the molar standard enthalpy of combustion, $\Delta \mathrm{H}_{\mathrm{c}}^{\circ}$, and the molar standard enthalpy of formation, 


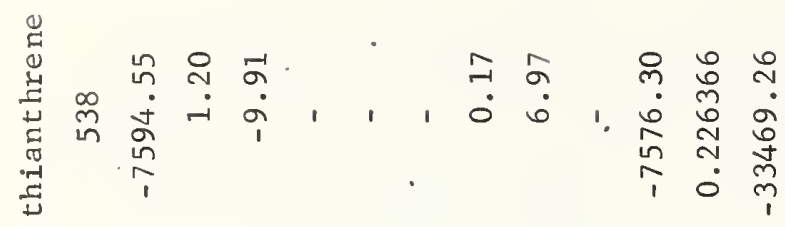

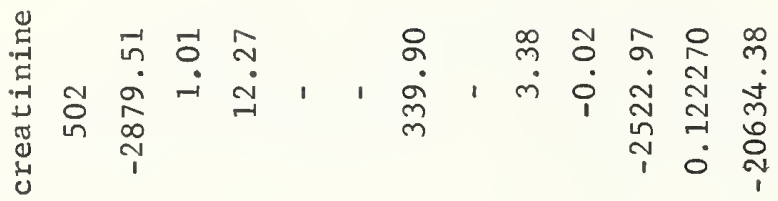

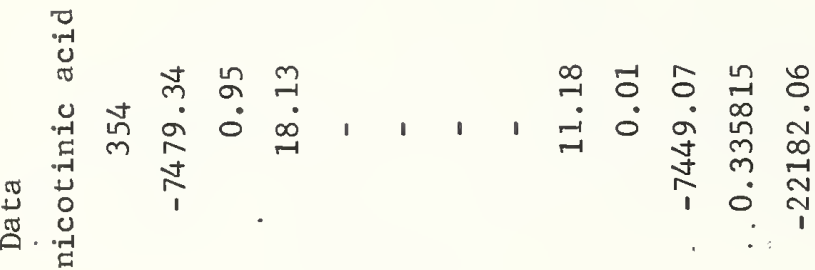

$\rightarrow$

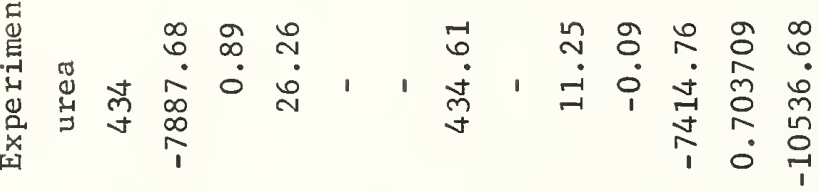

苟

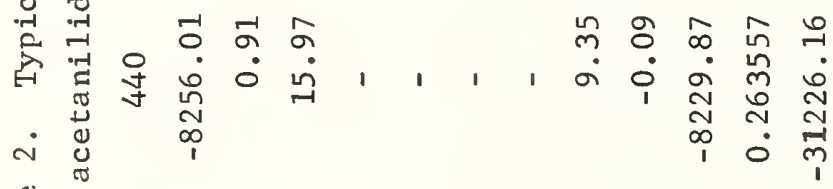

$\underset{\substack{0 \\ \rightarrow}}{\stackrel{0}{0}}$

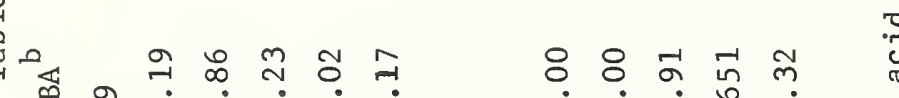

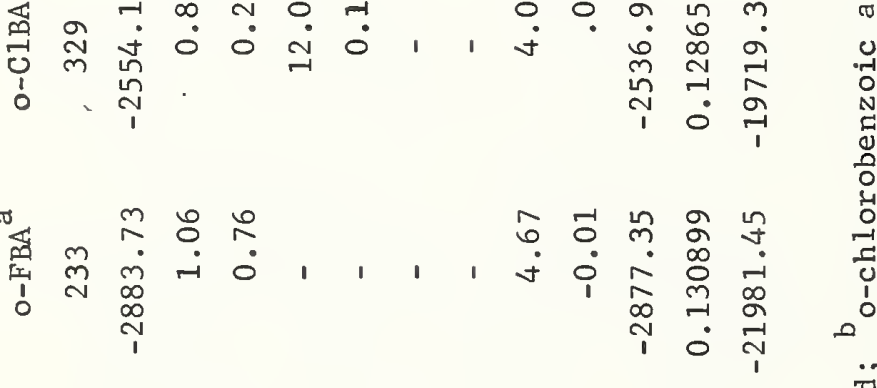

至 


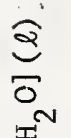

$$
\begin{aligned}
& \text { ब文 }
\end{aligned}
$$

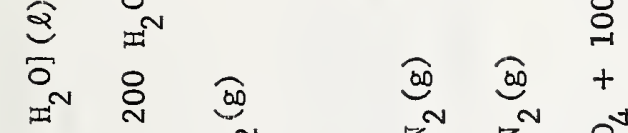

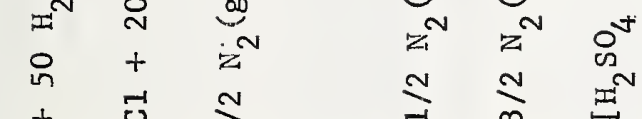

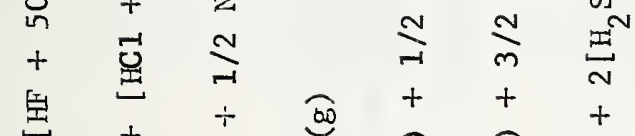

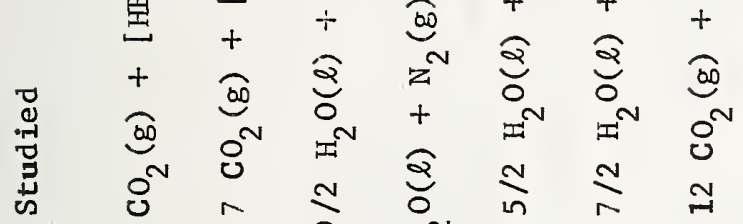

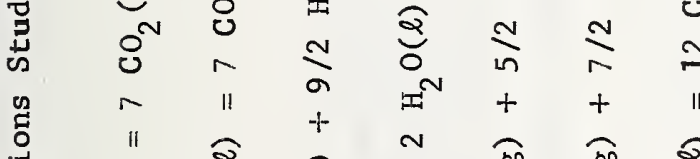

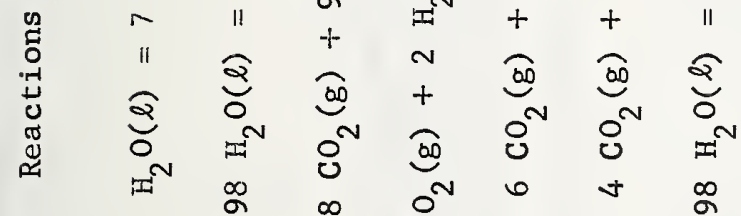

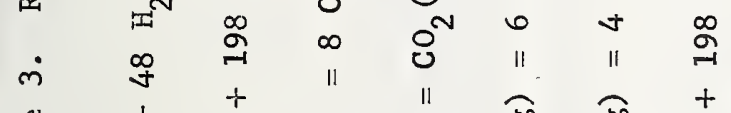

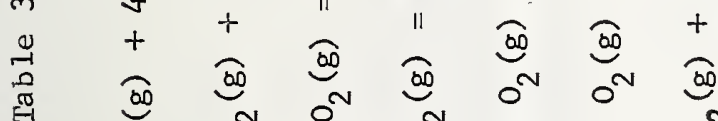

$$
\begin{aligned}
& \text { 蚫 }
\end{aligned}
$$

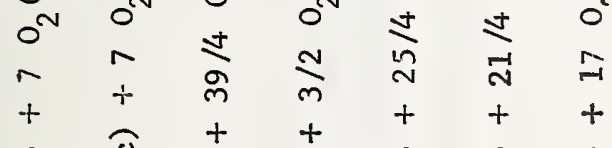

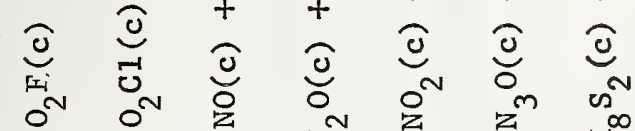

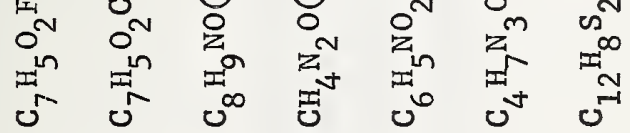

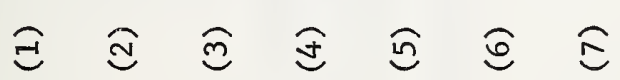


Oํ.-

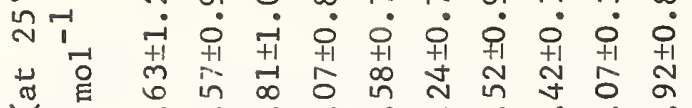

崩

苛

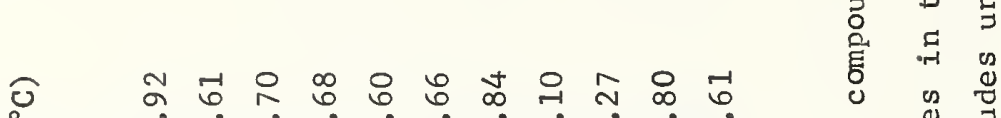

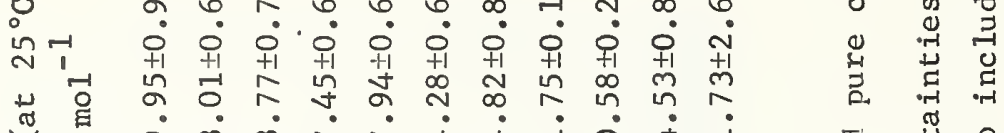
荡茎

ค ก 崩

ঋ

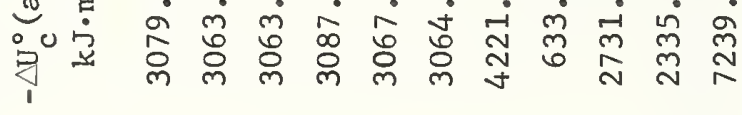
过

๘

其 \%

出

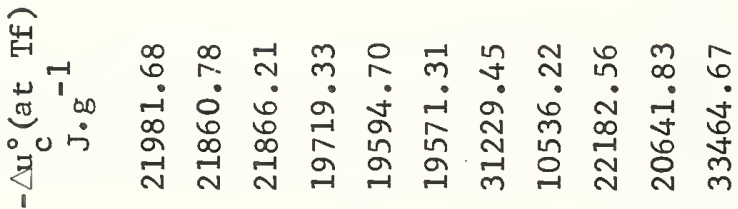

崔 U 要 (1)

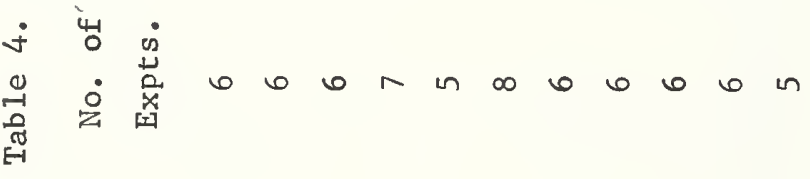

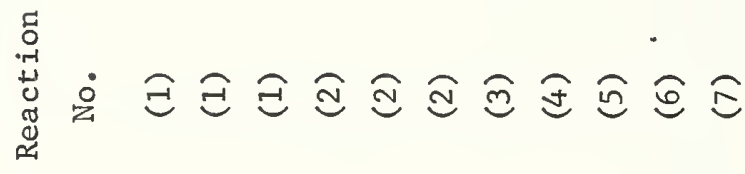

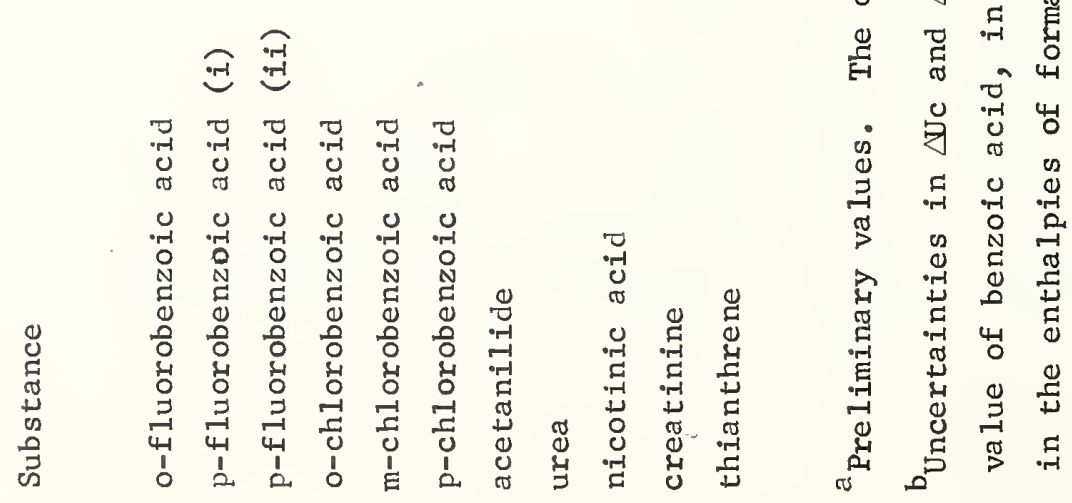




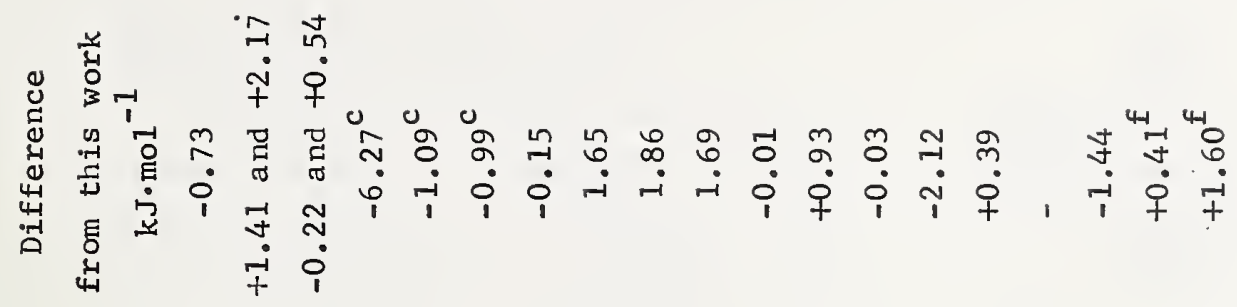

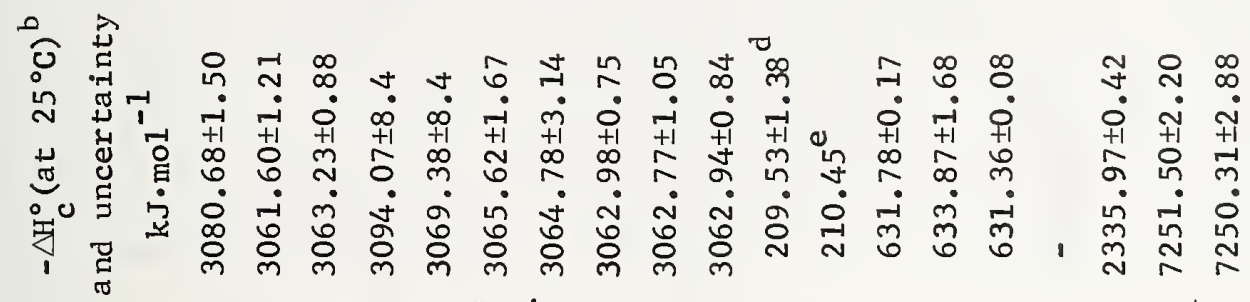

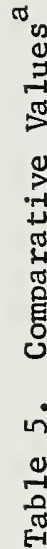

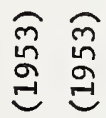

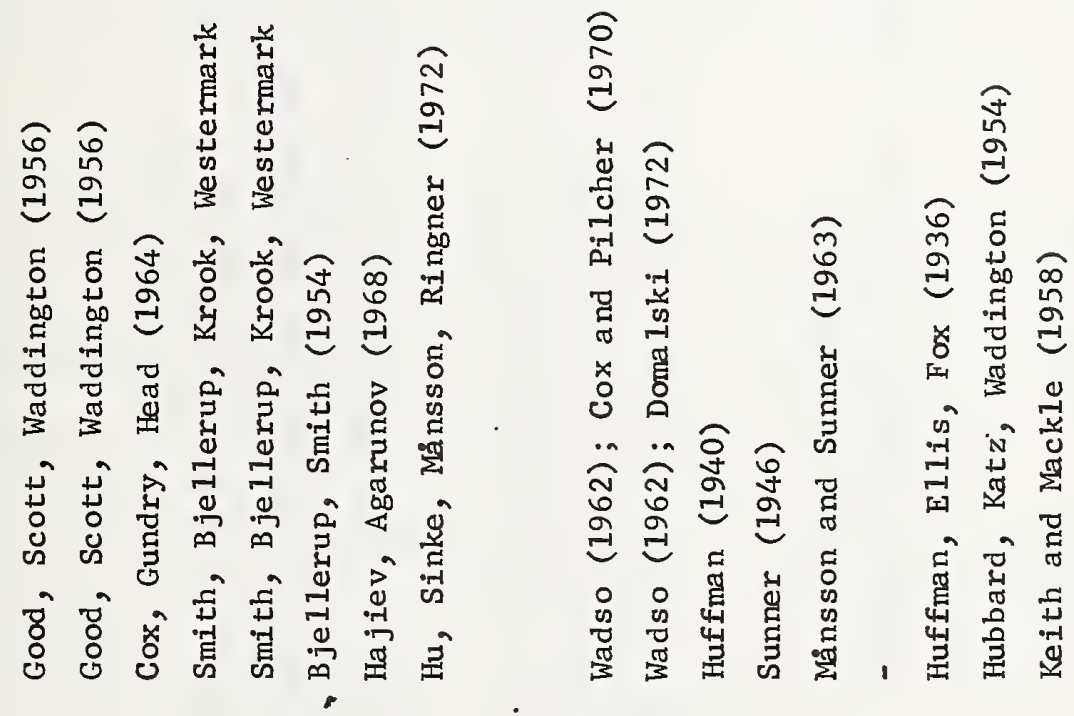

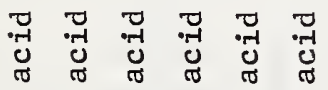

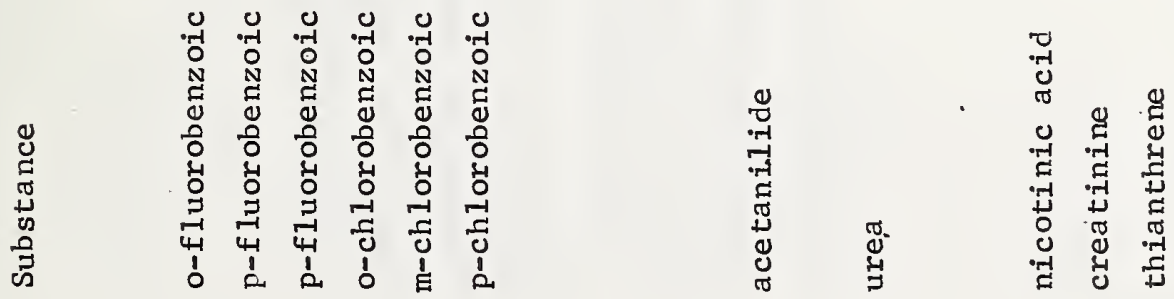



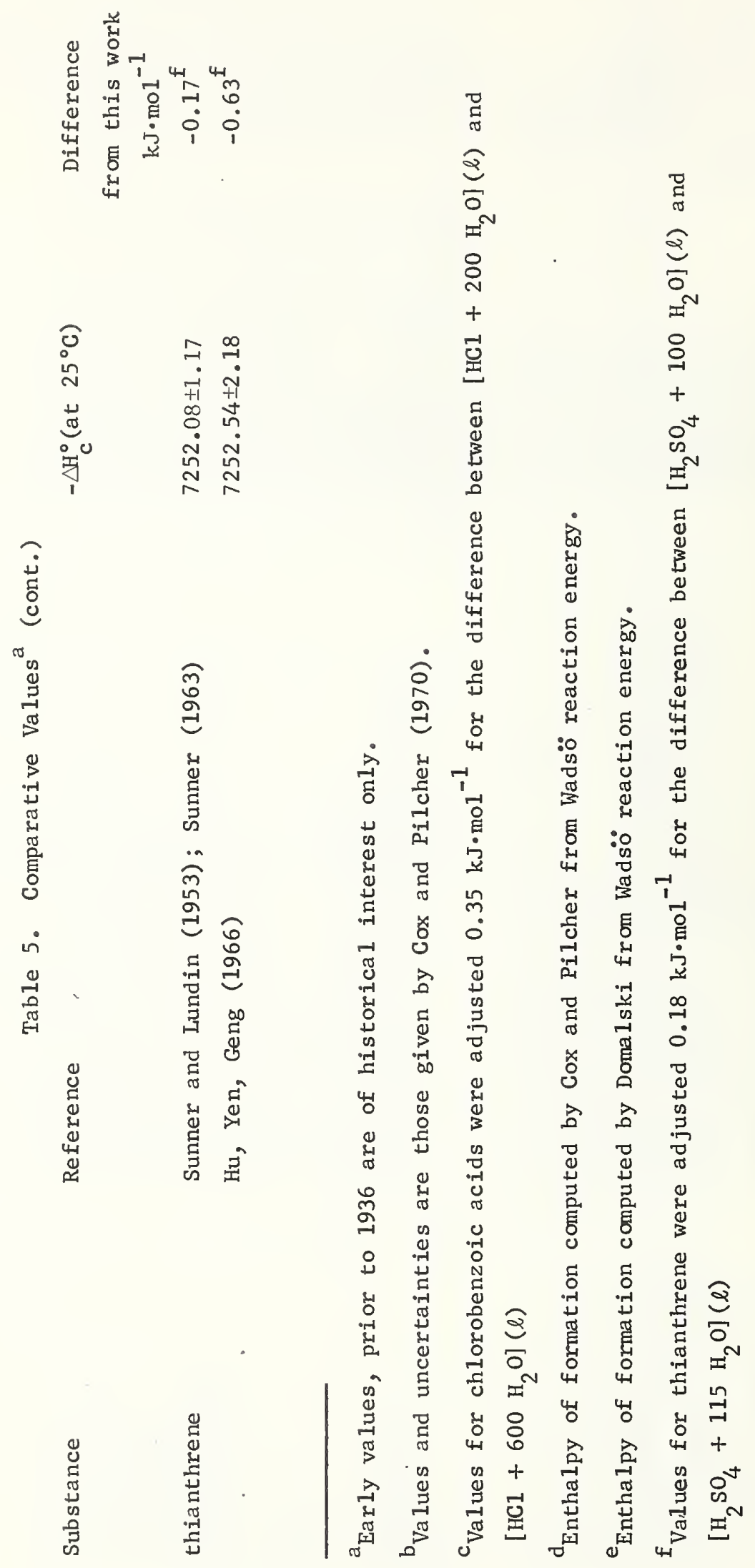
$\Delta \mathrm{H}^{\circ}$, at $25^{\circ} \mathrm{C}$, for each substance, together with the respective uncertainties of these quantities.

In reducing the data atomic weights were taken from the 1969 table of atomic weights. Enthalpies of formation of other substances were taken from Wagman, et al (1968). Washburn corrections were made by computer program based on equations generally taken from appropriate chapters of Experimental Thermochemistry, Rossini (1956) and Skinner (1962). The adaptations were made by Shomate (for $\mathrm{C}, \mathrm{H}, \mathrm{O}, \mathrm{N}$ compounds), and further modified by Armstrong, and by Prosen with respect to these compounds and to allow treatment of $\mathrm{F}$ compounds. The program for $\mathrm{Cl}$ compounds was provided by Mansson. No computer program for the $S$ compound was available so that the calculations were made following Hubbard, Scott, and Waddington (1956).

\subsection{Substances studied: characterization and observations.}

The studies which were carried out were not performed on samples that would form the proposed reference materials, but on materials already available. In some cases these were substances already certified as standard reference materials for other purposes.

\subsection{Fluorobenzoic acids}

A sample of o-fluorobenzoic acid and a sample of p-fluorobenzoic acid(i) obtained from W. D. Good (U.S. Bureau of Mines, Bartlesville) and a commercial sample of p-fluorobenzoic acid(ii) (J. T. Baker, Ultrex No. 4979) were tested as potential fluorine containing thermochemical standards. The fluorobenzoic acids from Good were the same as, used by Good, Scott, and Waddington (1956). The results obtained on the orthoacid in this work and in the Bureau of Mines work do not differ significantly. The results on the two samples of the para-acid do not differ significantly from each other or from the work of Cox, Gundry, and Head (1964). They do not agree as well with the results of Good, Scott, and Waddington (1956).

\subsection{Chlorobenzoic acids}

0-chlorobenzoic acid used was an NBS microanalytical standard; the m-chlorobenzoic acid was a conmercial sample (J. T. Baker, Ultrex No. 4976); and p-Chlorobenzoic acid was obtained from the Lund thermochemical laboratory, and was the sample used by Hu, Sinke, Mansson and Ringner (1972). Relatively large uncertainties are assigned by Cox and Pilcher (1970) to the work of Smith, Bjellerup, Krook, and Westermark (1953) on o-, and m-chlorobenzoic acids. The present results are well within these error limits. Bjellerup and Smith (1954) and Hajiev and Agarunov (1968) have reported measurements on p-chlorobenzoic acid which are in agree- 
ment with each other and with the present work. More recently Hu, Sinke, Minsson, and Ringner (1971) have reported three values determined in different calorimeters and which are at the limits of the combined errors.

In these experiments $\mathrm{As}_{2} \mathrm{O}_{3}$ was used to reduce chlorine formed in the combustion. The correction for this reaction of chlorine is listed in Table 2 as $\mathrm{q}_{A s}$. A difficulty was encountered in these experiments caused by the slow reaction of arsenious oxide with oxygen during the period after loading the bomb and before performing the heat measurement. This tended to cause an error in the determination of the amount of arsenic oxide formed during the reaction. It was found to be catalyzed by the platinum of the bomb lining in contact with the arsenious oxide solution. This difficulty was overcome by placing the arsenious oxide solution in a plastic container. A small correction, $\mathrm{q}_{\mathrm{Pt}}$, was applied for the formation of $\mathrm{H}_{2} \mathrm{PtCl}_{6}$ during the reaction.

\subsection{Acetanilide $\left(\mathrm{C}_{6} \mathrm{H}_{5} \mathrm{NHCOCH}_{3}\right)$}

The sample measured was NBS SRM $141 b^{1}$, certified as a material for microchemical analysis of $\mathrm{C}, \mathrm{H}$, and $\mathrm{N}$. The sample is indicated by its certificate to be 99.99 mole percent pure, and to be non-hygroscopic It had been purified by fractional crystallization from the melt. The enthalpy of formation calculated from our combustion measurements is in close agreement with the value obtained by Wadsö (1962) on the basis of the liquid phase reaction of acetic anhydride and aniline as calculated by Cox and Pilcher (1970) but in less good agreement with the value ca1culated by Domalski from the same reaction using different auxiliary data

\subsection{Urea (carbamide); $\left(\left(\mathrm{NH}_{2}\right)_{2} \mathrm{CO}\right)$}

The sample used was NBS SRM $912^{1}$, a standard obtained from a commercial source and certified for use in clinical analysis procedures. The observed enthalpy of combustion is in good agreement with that reported by Huffman (1940), and Mansson and Skinner (1963). Urea requires an igniter to obtain consistent combustion. Using benzoic acid for this purpose, very good precision is obtained. The energy from this small amount of benzoic acid is 1 isted in Table 2 as $q_{A u x}$. This sample had the best reproducibility of the samples tested.

\subsection{Nicotinic acid (pyridine-3-carboxylic acid); $\left(\mathrm{NC}_{5} \mathrm{H}_{4} \mathrm{COOH}\right)$}

The sample used was NBS SRM $148^{1}$, certified for microdetermination of

$\overline{1_{\text {See footnote }}}$ p. 5. 
C, H, X. Titrimetric assay indicates a purity of $99.99 \pm 0.08$ percent. No previous deteminations have been made of the combustion energy. This sample gave clean reproducible combustions without a promoter.

\subsection{Creatinine ( $\mathrm{HI}=\mathrm{\textrm {GN }}\left(\mathrm{CH}_{3}\right) \mathrm{CH}_{2} \mathrm{CONH}$}

The sample used was NBS SR $914^{1}$, certified for use in calibration and standarization of procedures used in clinical analysis. Its composition (percent) is stated to be: purity (99.8), volatile matter $(0.03)$, chloride $(0.07)$, ash $(0.003)$, insoluble natter $(0.001)$. The sample required an igniter to obtain complete combustions. The reproducibility was substantially poorer than for the other nitrogen compounds tested and larger samples led to incomplete combustion. The results were at about the limits of stated experimental error from those reported by fuffman, Ellis, and Fox (1936).

\subsection{Thianthrene $\left(\left(\mathrm{C}_{6} \mathrm{H}_{4}\right)_{2} \mathrm{~S}_{2}\right)$}

The sample was obtained comercially (Aldrich Chemical) and was zone refined with fifteen passes. The results were less reproducible than most of the other substances, but had about the same reproducibility as previously reported work. These measurements give an energy of combustion about midway between the results of Hubbard, Katz, and haddington (1954) and of Hu, Yen, and Geng (1966). They are in good agreenent with the results of Sunner (1963).

The thianthrene combustions led to a black finish on the platinum crucible, which on ignition led to a clean matte finish. The problem which this poses is not understood. The correction in Table 2, labeled $\mathrm{q}_{\mathrm{diln}}$ is the adjustment of the final solution to the standard concentration.

\subsection{Recomendations:}

The following tentative recomendations are made about the thermochemical reference materials program: (1) In the selection of a thermochemical reference naterial for comparative studies a criterion of difficulty should be used to insure that the reference material exemplifies a difficult problem characteristic of the class of substances it represents. (2) Urea is a reasonable reference material for nitrogen compounds because it requires an igniter to achieve consistent combustion, a problem characteristic of organic nitrogen compounds. (3) While p-chlorobenzoic acid and p-fluorobenzoic acid are low in halogens, the amount of experimental comparison work already done on them should be taken advantage of in selecting them as reference naterials. 
(4) Because the demand for thermochemical reference materials is likely to be light, the collection of reference materials certified for other purposes seems to be a reasonable source for the materials needed.

(5) Certification of thermochemical reference materials containing special elements should include references to work done on the same substance (the same or other batches) in other places as well as the standardizing laboratory. (6) Because the purposes of thermochemical reference materials include the discovery of sources of systematic or random errors, the use of rigidly defined procedures should not be overemphasized. Reasonable variations in procedures and instruments should be encouraged. (7) Comparis on of the results of measurements made in this work with measurements made elsewhere on the same substances indicates that differences between laboratories/samples/procedures lead to differences of 0.01 to 0.05 percent between well qualified scientists. Absolute differences of 0.2 to $2 \mathrm{~kJ} \mathrm{~mol}^{-1}$ are prevalent. 
Bjellerup, L., and Smith, L. (1954) Kg1. Fysiograph. Sållskap. Lund Förh. 24, 21.

Cox, J. D., Gundry, H. A., and Head, A. J. (1964) Trans. Faraday Soc. 60,653 .

Cox, J. D., and Pilcher, G. (1970) Thermochemistry of Organic and Organometallic Compounds, Academic Press, London.

Doma1ski, E. S. (1972) J. Phys. and Chem. Reference Data 1, 221.

Good, W. D., Scott, D. W., and Waddington (1956) J. Phys. Chem. 60, 1080 Hajiev, S. N., and Agarunov, M. J. (1968) J. Organomet. Chem. 11, 415. $\mathrm{Hu}$, A. T., Sinke, G. C., Månss on, M., and Ringnér, B. (1972), J. Chem. Thermodynamics $\underline{4}, 283$.

Hu, J-H, Yen, H-K, and Geng, Y-L (1966) Acta Chemica Sinica 32, 242. Hubbard, W. N., Katz, C., and Waddington, G. (1954) J. Phys. Chem. 58, 142 .

Hubbard, W. N., Scott, D. W., and Waddington, G. (1956) in Experimental Thermochemistry, F. D. Rossini, editor, Interscience Pub., NY, p. 75. Huffman, H. M. (1940) J. Am. Chem. Soc. 62, 1009. Huffman, H. M., Ellis, E. L., and Fox, S. W. (1936) J. Am. Chem. Soc. 58, 1728 .

Keith, W. A., and Mackle, H. (1958) Trans. Faraday Soc. 54, 353. Mansson, M., and Sunner, S. (1963) Acta Chem. Scand. 17, 723. Rossini, F. D. (1956) Experimenta1 Thermochemistry, Interscience Publishers, New York.

Scott, D. W., Good, W. D., and Waddington, G. (1956) J. Phys. Chem. 60, 1080 .

Skinner, H. A. (1962) Experimental Thermochemistry, Vo1. II, Interscience Publishers, New York.

Smith, L., Bjellerup, L., Krook, S. and Westermark, H. (1953) Acta Chem. Scand. 7, 65 .

Stohman, F. , Kleber, C. Langbein, H. and Offenhaver, P. (1893).

Stratton, S. W. (1911) The Standardization of Bomb Calorimeters, Circular Bur. Stand. No. 11, U.S. Government Printing Office, Wa shington, D.C., P. 10 .

Sunner, S. (1946) Svensk Kem. Tidr. 58, 71.

Sunner, S. (1963) Acta Chem. Scand. 17, 728.

Sunner, S., and Lundin, B. (1953) Acta Chem. Scand. 7, 1112.

Waddington, G. (1956) in Experimental Thermochemistry, F. D. Rossini, editor, Interscience Publishers, Inc., New York, p. 287-295. 
Wadsö, I. (1962) Acta.Chem. Scand. 16, 471.

Wagman, D. D., Evans, W. H., Parker, V. B., Hal ow, I., Bailey, S. M., and Schumm, R. H. (1968) Selected Values of Chemical Thermodynamic Properties, NBS Tech. Note 270-3, U.S. Government Printing Office, Washington, D.C. 
FORM NBS-I14A (1.71)

\begin{tabular}{|c|c|c|c|}
\hline $\begin{array}{l}\text { 1. PUBLIC ATION OR RE PORT NO. } \\
\text { NBSIR 73-158 }\end{array}$ & $\begin{array}{l}\text { 2. Gov't Accession } \\
\text { No. }\end{array}$ & \multicolumn{2}{|c|}{ 3. Recipient's Accession No. } \\
\hline \multicolumn{2}{|l|}{ 4. TIT LE AND SUBTITLE } & \multicolumn{2}{|c|}{ 5. Publication Date } \\
\hline \multirow{2}{*}{\multicolumn{2}{|c|}{$\begin{array}{l}\text { Standard Reference Materials for Combustion } \\
\text { Calorimetry }\end{array}$}} & \multicolumn{2}{|c|}{6 July 1973} \\
\hline & & \multicolumn{2}{|c|}{ 6. Performing Organization Code } \\
\hline \multicolumn{2}{|l|}{$\begin{array}{l}\text { 7. AUTHOR(S) } \\
\text { G. T. Armstrong and W. H. Johnson }\end{array}$} & \multicolumn{2}{|c|}{ 8. Performing Organization } \\
\hline \multicolumn{2}{|l|}{$\begin{array}{l}\text { 9. PERF ORMING ORGANIZATION NAME AND ADDRESS } \\
\text { NATIONAL BUREAU OF STANDARDS } \\
\text { DEPARTMENT OF COMMERCE } \\
\text { WASHINGTON, D.C. } 20234\end{array}$} & \multicolumn{2}{|c|}{$\begin{array}{l}\text { 10. Project/Task/Work. Unit No. } \\
3160275 \text { and } 3160110 \\
11 . \text { Contract/Grant No. }\end{array}$} \\
\hline \multirow{2}{*}{\multicolumn{2}{|c|}{ Office of Standard Reference Materials }} & \multicolumn{2}{|c|}{$\begin{array}{l}\text { 13. Type of Report \& Period } \\
\text { Covered } \\
\text { Interim Report }\end{array}$} \\
\hline & & \multicolumn{2}{|c|}{ 14. Sponsoring Agency Code } \\
\hline \multicolumn{4}{|l|}{ 15. SUPPLEMENT ARY NOTES } \\
\hline \multicolumn{4}{|c|}{$\begin{array}{l}\text { 16. ABSTRACT (A 200-word or less factual summary of most signific ant information. If document includes a significant } \\
\text { bibliography or literature surve } y \text {, mention it here.) }\end{array}$} \\
\hline \multicolumn{4}{|c|}{$\begin{array}{l}\text { Combustion measurements using a rotating bomb adiabatic aneroid calorimeter } \\
\text { have been used to make a preliminary evaluation of ten substances as potential } \\
\text { thermochemical reference materials for combustion or organic compounds containing } \\
\mathrm{N}, \mathrm{S}, \mathrm{C} 1 \text { and } \mathrm{F} \text {. p-chlorobenzoic acid, p-fluorobenzoic acid, and urea are } \\
\text { recommended for acquisition, certification, and distribution. Thianthrene } \\
\text { may also be suitable. For the ten substances including in addition to the above: } \\
\text { o- and m-chlorobenzoic acids, o-fluorobenzoic acid, nicotinic acid, acetanilide, } \\
\text { and creatinine, typical combustion data are given, showing corrections applied; } \\
\text { and mean thermodynamic functions at } 25^{\circ} \mathrm{C} \text { are given together with error estimates. } \\
\text { The results are compared with other work. Recommendations and a discussion of } \\
\text { the role of standard reference materials for thermochemistry are given. }\end{array}$} \\
\hline \multicolumn{4}{|c|}{$\begin{array}{l}\text { 17. KEY wORDS (Alphabetical order, separated by semicolons) Acetanilide; bomb calorimetry; calorimetry; } \\
\text { chlorobenzoic acid; combustion; creatinine; fluorobenzoic acid; nicotinic acid; } \\
\text { reference materials; thermochemical; thermochemical standards; thianthrene; urea. }\end{array}$} \\
\hline \multicolumn{4}{|c|}{ 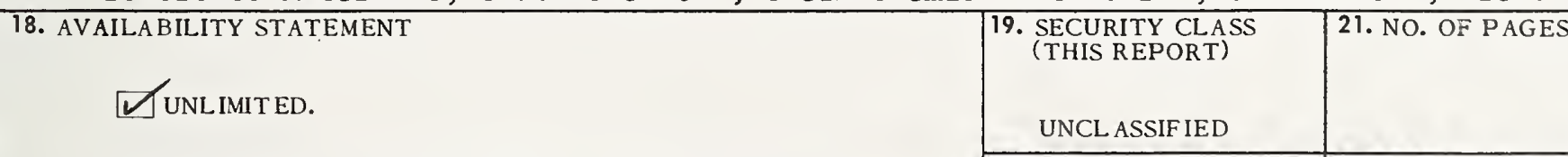 } \\
\hline \multirow[t]{2}{*}{$\begin{array}{l}\square \text { FOR OFFICIAL DISTRIBUTION. DO NOT RELEASE } \\
\text { TO NTIS. }\end{array}$} & $\begin{array}{l}\text { 20. SECURI } \\
\text { (THIS P }\end{array}$ & $\begin{array}{l}\text { CLASS } \\
\text { CE) }\end{array}$ & 22. Price \\
\hline & & & \\
\hline
\end{tabular}




